\title{
Using action research based on the predict-observe-explain strategy for teaching enzymes
}

\author{
Kadir Bilen \\ Alanya Alaaddin Keykubat University, Faculty of Education, Department of Elementary Education, Alanya, \\ Turkey, kadirbilen@gmail.com \\ Murat Özel \\ Niğde University, Faculty of Education, Department of Elementary Education, Niğde, Turkey, \\ mozeltr@gmail.com \\ Sacit Köse \\ Pamukkale University, Faculty of Education, Department of Elementary Education, Denizli, Turkey, \\ sacitkose@gmail.com
}

\begin{abstract}
The science laboratory course is one of the important courses that preservice science students take in their science education programs. The purpose of this study is to investigate the impact of an action research based on the POE (predict-observe-explain) strategy on preservice science teachers' understanding of enzymes. The participants of the study consisted of 80 sophomore preservice science teachers who enrolled in a science teaching laboratory course at a public university in Turkey. The data were obtained through the POE forms. The findings showed that the use of POE activities promoted significantly students' understanding of enzymes. It was also found that although preservice science students indicated that activities based on the POE approach took more time compared to other instructional strategies, they emphasized that the POE activities were enjoyable compared to other instructional strategies. Based on the results obtained from this study, it is suggested that using the POE method in the science laboratory courses will contribute to preservice science teachers' understanding of science topics.
\end{abstract}

Keywords Action research, science laboratory, predict-observe-explain (POE) strategy, enzymes

\section{Tahmin- gözlem- açıklama stratejisine dayalı bir eylem araştırması: enzimler}

ÖZ Fen laboratuvar uygulamaları, eğitim fakültelerindeki sınıf öğretmenliği öğrencilerinin alması gereken önemli bir derstir. Bu araştırmanın amacı Tahmin-Gözlem-Açıklama (TGA) yöntemine dayalı eylem araştırmasının öğretmen adaylarının enzimleri anlamaları üzerine etkililiğini incelemektir. Araştırmanın katılımcılarını 80 fen bilgisi öğretmen adayı oluşturmaktadır. Araştırmanın verileri TGA formları yoluyla toplanmıştır. Araştırmadan elde edilen sonuçlar (TGA) yöntemine dayalı eylem araştırmasının öğretmen adaylarının enzimleri anlamalarını arttırdığını ortaya koymuştur. Ayrıca sonuçlar TGA etkinliklerinin öğretmen adaylarının derse yönelik ilgilerini ve enzimler konusundaki anlamalarını arttırdığını ortaya çıkarmıştır. Bulgular aynı zamanda öğretmen adaylarının TGA stratejisini biraz zaman alıcı ve zorlayıcı olduğunu belirtmelerine rağmen, laboratuvardaki diğer yöntemlerden daha zevkli ve etkili olduğunu belirttiklerini göstermektedir.

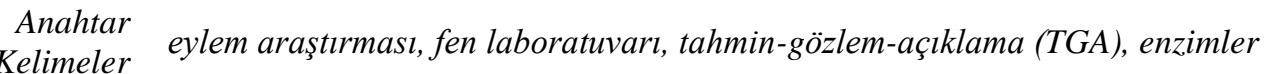




\section{GENIŞLETILMIŞ ÖZET}

Günümüz bilim ve teknoloji çağında giderek önemi artan fen bilimlerinin daha iyi anlaşılması için okullarda verilen fen eğitimi önemli bir yer tutmaktadır. Fen bilgisi derslerinin kalıcı bir şekilde anlaşılması, günlük hayatla ilişkilendirilebilmesi için öğrenciler yaparak yaşayarak öğrenmeli ve yeni bilgileri günlük hayattaki bilgilerinin üstüne yapılandırmalıdır (İşman, 1999). Yip (1998) fen konularında kavramsal anlamayı artırmak için, öğretmenlerin konuları yapılandırmacı öğretim modeline göre donatarak öğretmesi ve dolayısıyla doğrudan bilgi transferinin üzerinde duran geleneksel öğretim modelinden vazgeçirilmesi gerektiğine dikkati çekmektedir.Laboratuvar, öğrencilerin günlük yaşam ile doğrudan ilişkili olan fen konu ve kavramlarını daha etkili ve anlamlı bir biçimde öğrenmelerine olanak vermesi ve öğrencilere gerçek yaşam deneyimleri kazandırması bakımından önemlidir. Laboratuvar öğrencilerin yaparak-yaşayarak öğrenmelerine imkan sağladığ1 için fen öğretiminde önemlidir (Ayas, 2006). Laboratuvarda öğrenciler teorik olarak öğrendiklerini pratiğe dönüştürebilirler. Laboratuvarda öğrencileri aktif hale getirmenin yolu onların deney üzerinde çalışmaları ve düşünmelerine olanak sağlayacak yöntemler kullanmaktır. Tahmin-Gözlem-Açıklama (TGA) stratejisinden bu bakımdan yararlanılabilir (Tekin, 2008). TGA stratejisidir. TGA aktiviteleri üç aşamadan oluşur: 1- Tahmin aşaması, 2-Gözlem aşaması ve 3- Açıklama aşaması (Köseoğlu, Tümay ve Kavak, 2002; Köse, Coştu ve Keser, 2003). Biyolojide enzimlerin anlaşılmasıyla ilgili az sayıda araştırma bulunmaktadır. Örneğin, Lazarowitz ve Penso (1992) biyolojide öğrenilmesi güç olan konuların arasında enzimin yapısı ve fonksiyonunun yer aldığını belirtmişlerdir. Bu sonucun iki nedeni bulunmaktadır. Birincisibiyoloji konularının öğretiminde bütünlüğün yakalanamamasıdır. İkincisi ise bu konuların soyut olan konular arasında yer almasıdır.

Çalışmada eylem araştırması yaklaşımı kullanılmıştır. Literatürde "action research" olarak adlandırılan eylem araştırması, öğretmenlerin öğretimleri esnasında yaşadıkları sorunlara ilişkin araştırma sürecine girmeleri ve öğretimlerini iyileştirmek için planlanan belirli bir süreci içermektedir. Bu bakımdan eylem araştırması var olan öğretim sürecinin iyileştirilmesi için önceden planlanan çalışmaların tamamı olarak tanımlanabilir. Eylem araştırmasının birincil amacı, bireylerin günlük yaşantılarında işe yarayacak uygulamaya dayalı bilgiler elde etmektir. Eylem araştırması öğretmenin öğretiminin kalitesini arttırmayı hedeflemektedir. (Ekiz, 2003). Öğretimin kalitesini artırmak ve öğrencilerin anlamlı öğrenmelerini sağlamak eğitimin önemli hedefleri arasında yer almaktadır. Bu hedeflere ulaş1lmada öğretmenlere önemli görevler düşmektedir (Küçük, 2002; Ekiz, 2003; Tekin, 2008).

$\mathrm{Bu}$ araştırma Pamukkale Üniversitesi Eğitim Fakültesi sınıf öğretmenliği programındaki "fen ve teknoloji laboratuvar uygulamaları I" dersini alan 80 öğrenci ile yürütülmüştür. Örneklem seçimi amaçlı veya olasılık dışı örnekleme stratejisinin kritik durum örneklemesi ile belirlenmiştir. Enzimler konusunda TGA stratejisine dayalı etkinlikler sonucunda öğretmen adaylarının enzimler konusunu öğrenmede zorlandıkları ve bu konuda önceden birçok kavram yanılgısına sahip oldukları görülmektedir. $\mathrm{Bu}$ araştırmadan elde edilen sonuçlar Tahmin-Gözlem-Açıklama (TGA) yöntemine dayalı eylem araştırmasının öğretmen adaylarının enzimleri anlamalarını arttırdığını ortaya koymuştur. Ayrıca sonuçlar TGA etkinliklerinin öğretmen adaylarının derse yönelik ilgilerini ve anlamalarını arttırdığını ortaya çıkarmıştır. Bu bağlamda fen öğretiminde TGA stratejisinin daha sıklıkla kullanılması gerektiği önerilmektedir. 


\section{INTRODUCTION}

Science education is highly important in the area of current scientific and technological developments. As it is known, the purpose of science education in many countries is to help students to become scientific literacy persons (Ministry of National Education of Turkey 2013; National Research Council, 1996). In light of this aim, a variety of instructional strategies have been used to promote students' understanding of science topics. Among these strategies, the predict-observe-explain (POE) strategy has been suggested by many researchers to promote students' understanding of science topics (Bilen \& Köse, 2012a; Bilen \& Köse, 2012b; Liew \& Treagust, 1995). Research studies (Bilen \& Köse, 2012a; Bilen \& Köse, 2012b; Liew \& Treagust, 1995) have revealed that the use of the POE strategy helped to increase students' conceptual understanding of science topics.

In the science education literature, it is well known that students experience misconceptions or misunderstandings regarding science concepts. It is reported that traditional education is not effective in removing students' misconceptions in science teaching (Bilen \& Köse, 2012a). As suggested by Yip (1998), teachers should use the constructivist teaching model in order to increase conceptual learning and abandon traditional teaching models which emphasize direct transfer of knowledge. In this regard, the POE is one of the instructional strategies that enable students to learn science concepts using constructivist teaching by associating learners' prior knowledge with new information (Bilen \& Köse, 2012a; Liew \& Treagust, 1995). Scholars have already suggested that the POE method is helpful to promote students' conceptual understanding of science topics and to reduce their misconceptions. The POE method is compatible with constructivist learning theory. According to the constructivist learning theory, students should be encouraged to explain their own ideas during education (prediction phase), they should be brought in contact with situations that challenge their ideas (observation phase) and they should be encouraged to form hypotheses and generate alternative interpretations to events (prediction and explanation phases). Students should be given opportunities to think alternative ideas especially through small group discussions (explanation phase) and to utilize these new ideas in various situations so that students can understand the benefits of new ideas (Clayton, 1993; Driver \& Bell, 1986). Therefore, the principles generated by constructivist learning theory for effective teaching are easily implemented when the POE method is used. However, there are only a few studies that have focused on the impact of the POE strategy on understanding of biology concepts.

In the field of science education, a limited number of studies have examined students' learning about enzymes. A study by Lazarowitz and Penso (1992) stated that the structure and functions of enzymes were considered as difficult due to two reasons. The first reason was the inability to obtain integrity at the level of biological organization and the second reason was the abstraction of some subjects. Bahar (2003) also showed that students had difficulty with regard to enzymes. Results of studies on enzymes in the literature reveal that students have misconceptions (Emre andYılayaz, 2006; Selvi and Yakışan, 2004). For example, regarding the general characteristics of enzymes, the majority of students tended to think there was only one enzyme specific to each substratum (Brettz \&Linenberger, 2012). There were also a large number of students who thought that enzymes were specific to only living beings. Misconceptions regarding the relationship of temperature and $\mathrm{pH}$ values with enzyme activities were also identified (Linenberger\& Brettz, 2015; Lau, 2013). These misconceptions were found to be related to the fact that although the subject was explained in textbooks, the topic on enzymes was not sufficiently understood. For instance, although the effect of temperature on enzymes is provided in many resource books, the focus is mostly on the effect of high temperatures while the effect of low temperatures on enzymes is not generally mentioned (Emre\&Yılayaz, 2006; Sinan, Köse, Aydın, \& Gezer, 2007; Sinan, Yıldırım, Kocakülah, \& Aydın, 2006). Due to the limited number of studies on enzymes, the current study is focused to facilitate students' understanding of enzymes.

\section{Purpose of the Study}

The present study aimed to promote students' understanding of enzymes using an action research method involving the use of the POE instructional strategy. With this in mind, the following research question guided the present study:

What is the effect of using action research based on the predict-observe-explain strategy in facilitating preservice teachers' understanding of enzymes? 


\section{METHOD}

This section includes the research model, research process, participants, data collection, and analysis.

\section{Research Model}

The study utilized the action research approach. Action research is a systematic intervention process based on research about personal professional actions to engender change (Costello, 2007). Therefore, action research can be defined as the entirety of systematic work undertaken to improve working conditions by the individuals in the system (Sagor, 2000). The primary aim of action research is to obtain practice-based information that can be useful in daily life. The main rationale in the selection of this approach is to provide the teachers with a philosophy that will increase the quality of classroom teaching (Ekiz, 2003).

The action research method can be implemented in eight stages. These are identification of the problem, discussing the problem with colleagues and clarification of research questions, conducting a literature review, transformation of identified questions into research problems, decision making regarding research process, decision making regarding assessment and evaluation, implementation of possible solutions, and interpretation of obtained data.

The problem of the present study was determined in the following steps. First, it was found that all students who enrolled in science teaching laboratory applications course did not conduct the same experiments due to lack of laboratory equipment. Second, as result of the shortage of materials, there was no classroom environment in which students would be able to share their thoughts when conducting experiments. Third, it was also found that, in general, students were doing experiments as verification suggested by the instructor or the laboratory book. Thus, the experiments seemed to be like conducting cookbook experiments. It was clear that verification experiments did not allow students to explore any problems during the experiments. Therefore, researchers and instructors decided that the use of the POE method would be a better way to encourage students to explore science topics during the course. With this aim, the topic of enzymes was chosen for the present study. Accordingly, the teaching of enzymes was organized based on the POE method.

\section{Participants}

The participants were 80 preservice classroom students who enrolled in the science and technology laboratory practices I course at Pamukkale University, Turkey. An appropriate sampling method was used to involve participants in the study. All the participants were from two different classes. Since the laboratory was not suitable for all 80 students to work together, the class was divided into four groups and the experiments were undertaken with 20 students in each group.

\section{Data Collection}

POE activities developed for the enzymes unit were used as data collection tools. Three experiments were used for teaching enzymes. The first experiment focused on the relationship between substrate surface and enzyme speed, while the second experiment included the treatment of a whole piece of liver with hydrogen peroxide first and later the treatment of liver pieces with the same weight as the whole liver with hydrogen peroxide and in the final step the treatment of the whole piece of liver with hydrogen peroxide after the liver was boiled. The third experiment consisted of activities regarding the relationship between temperature and enzymes. In this action research, the participant observation method was used and researchers took field notes during lab experiments (Ekiz, 2003; Tekin, 2008). These notes comprised of one of the data resources used in the study. POE worksheets filled by students and the views of students regarding the efficiency of implementation of the POE method were included in the data.

Data were collected over four weeks in order to ensure plausibility about the reliability and validity of the current study. Data analysis was provided regularly during the research process. Thus, problems that the instructor faced were shared with researchers in committee meetings held weekly during the research. Expert views both in the field of content knowledge and qualitative research were considered during the planning, implementation and conclusion stages. Data analysis was undertaken in consensus with expert views and results were shared with the experts to obtain their ideas and suggestions. Research data were collected through various data collection tools of action research and 
their relationships were taken into account. In order to provide transmissibility, researchers ensured the use of clear and comprehensible language. In order to ensure consistency, concepts were considered in the same manner. Confirmation was provided clearly by presenting the supporting data for each activity undertaken during the implementation phase.

\section{Data Analysis}

Descriptive analysis was used to analyze the data. Direct quotations were used to reveal participants' views of the POE activities. For data analysis, researchers examined the data and analyzed them separately. The validity committee that met regularly every week examined the data from the activities of the previous week, made suggestions and proposed solutions regarding the problems that were encountered and made decisions that were recorded in the decision book. Based on the data obtained from the validity committee, action plans were developed to be implemented again and data were recollected to be analyzed. This procedure continued until the data were repetitive and the research was concluded by writing the results and suggestions based on the findings. Since the validity committee's decisions affected the action cycle to a great extent, a committee decision book was kept to record decisions after each meeting. Explanations reflecting the interviews during the meeting were recorded under the heading "findings" and the decisions made during meetings were recorded under the heading "decisions".

The same process was followed in the analysis of interview data. In order to ensure objectivity, the identified themes and related explanations were presented to another expert whose consent was sought. The expert examined $20 \%$ of the data independently and later compared them with the records kept by the researchers. Comparisons showed that the records were consistent with each other and a consensus was reached on the identification of themes and codes.

\section{FINDINGS}

The study followed the process described in the method section. All groups were given the same experiments to increase the level of comprehension regarding the experiments. Hence, a shared work and discussion environment was created in the laboratory and the results obtained from experiments could be discussed with the whole class. Tables 1, 2 and 3 present the findings related to the activities.

Table 1. Findings regarding POE Activity 1

\begin{tabular}{|c|c|c|}
\hline $\begin{array}{l}\text { Activity Question } \\
\text { What can you say about the reaction velocity in tubes? }\end{array}$ & $\mathrm{f}$ & $\%$ \\
\hline \multicolumn{3}{|l|}{ Student Predictions } \\
\hline III $>$ II $>$ I (correct answer) & 45 & 56,2 \\
\hline $\mathrm{I}=\mathrm{II}=\mathrm{III}$ & 26 & 32,5 \\
\hline $\mathrm{III}<\mathrm{II}<\mathrm{I}$ & 9 & 11,3 \\
\hline \multicolumn{3}{|l|}{ Results of Student Observations (Experiments): } \\
\hline III $>$ II $>$ I. & 80 & 100 \\
\hline \multicolumn{3}{|l|}{ Student Explanations } \\
\hline I made a correct prediction & 45 & 56,2 \\
\hline I made an incorrect prediction, I did not know the relationship of enzymes with surface. & 13 & 16,3 \\
\hline I realized I had misconceptions about enzymes. & 12 & 15 \\
\hline When the surface area increased, enzymes moved faster & 3 & 3,75 \\
\hline Other & 7 & 8,75 \\
\hline
\end{tabular}

As can be seen in Table 1, findings regarding Activity 1 show that $56.2 \%$ of the students made correct predictions, whereas $43,8 \%$ of the students made incorrect predictions. It can be claimed that students either had incomplete or incorrect knowledge regarding the relationship between the substrate surface and enzymes.

Table 2. Findings regarding POE Activity 2

\section{Activity Question}

$2 \mathrm{ml}$ hydrogen peroxide and equal amount of liver are added in each of the three test tubes in the $\mathrm{f} \%$ figure. Which tube does not have $\mathrm{O}_{2}$ efflux? 


\begin{tabular}{|c|c|c|}
\hline \multicolumn{3}{|l|}{ Student Predictions } \\
\hline 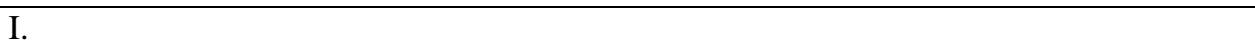 & 23 & 28,7 \\
\hline III. & 34 & 42,6 \\
\hline I and III (correct answer) & 23 & 28,7 \\
\hline \multicolumn{3}{|l|}{ Results of Student Observations (Experiments): } \\
\hline Test tubes I and III did not have $\mathrm{O}_{2}$ efflux. & 80 & 100 \\
\hline \multicolumn{3}{|l|}{$\begin{array}{c}\text { Student Explanations : } \\
\end{array}$} \\
\hline I predicted correctly & 23 & 28,7 \\
\hline I predicted incorrectly since I did not know how enzymes are affected from heat and cold & 34 & 42,6 \\
\hline We saw that enzyme structures are affected from heat and cold in the same way. & 23 & 28,7 \\
\hline
\end{tabular}

Findings in Table 2 regarding Activity 2 show that $28.7 \%$ of the students made correct predictions while $71,3 \%$ of the students made incorrect predictions. It is likely that students had incomplete or incorrect knowledge regarding the relationship between enzymes and temperature. Results revealed that preservice teachers held the misconception that enzymes do not work only in cold temperatures since the majority of students claimed that there would be no $\mathrm{O}_{2}$ efflux in III.

Table 3. Findings regarding POE Activity 3

\begin{tabular}{|c|c|c|}
\hline \multicolumn{3}{|l|}{ Activity Question } \\
\hline $\begin{array}{l}\text { If equal amounts of iodine are added to three test tubes, which tubes will change } \\
\text { their color to blue? (Iodine turns blue with starch) }\end{array}$ & f & $\%$ \\
\hline \multicolumn{3}{|l|}{ Student Predictions } \\
\hline Only II & 56 & 70 \\
\hline Only I (correct answer) & 4 & 5 \\
\hline I and II & 17 & 21,25 \\
\hline I and III & 3 & 3,75 \\
\hline \multicolumn{3}{|l|}{ Results of Student Observations (Experiments): } \\
\hline It was observed only in I. & 80 & 100 \\
\hline \multicolumn{3}{|l|}{ Student Explanations: } \\
\hline $\begin{array}{l}\text { I made an incorrect prediction. I did not know that temperature damaged } \\
\text { enzyme structure. }\end{array}$ & 51 & 63,75 \\
\hline I did not know the relationship between starch and saliva. & 14 & 17,5 \\
\hline I predicted correctly. & 4 & 5 \\
\hline $\begin{array}{l}\text { I knew that iodine is a reagent of starch but I could not correctly predict the } \\
\text { relationship with temperature. }\end{array}$ & 11 & 13,75 \\
\hline
\end{tabular}

Table 3 shows that, in activity 3, only $5 \%$ of the students made correct predictions whereas $95 \%$ of the students made incorrect predictions. It was observed that students had incomplete or incorrect knowledge regarding the type of tube in which the effect would be observed although they had already learned about the relationship between temperature and enzymes in the previous activity.

\section{Findings and Comments Regarding Student Views about the POE Method}

Students were asked the following question after the course to elicit their views regarding POE: "Was the use of POE in the science laboratory effective for you to better understand the concepts?" The majority of students experienced satisfaction regarding the practice. Students' answers regarding POE were examined in three categories (positive, negative and neutral) in line with expert views. Twentyfour students expressed negative views regarding POE, 50 students had positive views andsix students had neither positive nor negative ideas about the role of POE in promoting their understanding of the experiments.

Samples of negative student views are provided below:

S1: You have to ponder all the time during POE. I don't know what to write in the prediction phase because I don't have sufficient information about the subject before the experiment. At the same time, POE takes a lot of time...

S2: We are always writing. It requires a lot of time. 
S3: In my opinion it was not effective at all. I could not write my predictions since I was feeling averse to making mistakes.

As indicated by the above quotes, students expressed negative views since they had difficulty in the prediction phase which is the most difficult step of POE. Lack of time to take notes can be a disadvantage of POE. Samples of positive student views are provided below:

S1: Before the experiment, we recall prior knowledge with the use of predictions and can learn how much we are informed of a certain subject. Later we realize which information is incorrect during the observation phase and reinforce the correct information.

S2: In my opinion subjects are learned better through prediction, observation and explanation. We had difficulty in predictions but later we were better able to observe the points that were wrong in our observations.

S3: It is a different method for me. It is more effective in terms of participation during class, you have to do something all the time. You cannot only be an observer.

S4: We were directly implementing the experience in the other methods we used before. When I make predictions, I have questions for which I could find answers later.

Investigation of student views that POE is a more effective method shows that students believed the $\mathrm{POE}$ is more effective due to its difference. As opposed to students expressing negative views, students with positive views believed that having hardship during the prediction phase will help them understand the experiment better. Samples of student views that made neutral comments are provided below:

S1: I believe both the traditional laboratory method and POE have advantages and disadvantages. I am not sure whether POE is more effective.

S2: It is a different method, I am not sure if it helped me to understand the experiment or not.

\section{DISCUSSION and CONCLUSION}

The study aimed to identify what can be done to overcome the problems in teaching the subject of enzymes and to determine the contribution of experiments conducted using the POE strategy on students' understanding. The action research approach was used in tackling the research problem and several solutions were developed and implemented. As a result of activities developed based on the POE approach, it was concluded that preservice teachers had difficulties in learning the subject of enzymes and held many misconceptions. For instance in Activity 2, only $28.7 \%$ ( $\mathrm{f}=23$ ) of teacher candidates did know that enzyme activities can take place at very high or low temperatures. This finding is compatible with the related literature (Emre\&Yılayaz, 2006; Selvi\&Yakışan, 2004). Francis and Sellers (1994) and Sinan et al. (2007) also identified that proteins have enzymatic, structural and highly complex roles in cells and organisms and there are difficulties involved in learning them.

There may be several reasons for this difficulty. The first reason is related to the inability to embrace integrity at the level of biological organization and the second reason is related to the existence of some abstract subjects. Lazarowitz and Penso (1992) stated that the structure and functions of enzymes are among difficult subjects to learn both by teachers and students due to understanding problems. Examination of student answers in Activity 3 shows that only $4(5 \%)$ students could answer correctly during the prediction phase. As reflected by student answers, another handicap in their learning about enzymes stems from misconceptions that preservice teachers have. According to Sinan et al. (2007) students should know that enzymes are composed of proteins before they learn the subject of enzymes. Although students are previously taught that specific information in the general biology class, it is observed that they cannot use this information in the laboratory environment. The importance of the POE method implemented in the current study can be inferred from this example. Another result obtained from the current study is the fact that preservice teachers perceive the impact of enzymes in various situations as a very complex phenomenon. Findings supporting this result can be found in the literature (Emre and Y1layaz, 2006; Sinan et al., 2007; Sinan et al., 2006). 
Based on notes taken during observations, doing the same experiments by all groups in the science lab was found to be more effective in increasing student-student and student-instructor interactions and understanding about the theoretical foundations of the experiment. Various studies on teachers have identified that laboratory practices are highly important in science classes but they are not conducted appropriately (Ayas et al., 1994; Ekici, 1996; Yeşilyurt, 2005). In this context, it can be claimed that the POE method should be used more often in science labs.The POE method enables teacher candidates to notice misconceptions or lack of information during the prediction phase. This result demonstrates the need to use methods that consider prior knowledge and misconceptions. Both the national and international literature emphasize that compared to traditional ones, methods based on conceptual change are more effective in correcting the misconceptions of students/teacher candidates and increasing their achievement. Various studies in the literature show that the POE method is used in identification of misconceptions (Russell, Lucas and McRobbie, 1999; Tao \& Gunstone, 1999; Liew \& Treagust, 1995, 1998; Kearney \& Treagust, 2001; Mthembu; 2001; Köseoğlu et al., 2002; Köse, Bilen \& Uçak, 2010).

It was observed that students lacked information or held misconceptions about the subject although they did the experiments in the science lab themselves (Bilen, 2009; Bilen and Aydoğdu, 2010). In other words, although students were given information about the experiment prior to the experiment (such as prior knowledge regarding the fact that enzymes are not active at every temperature), the students still interpreted the experiment differently. Therefore, it is possible to claim that discussing the results in the class especially after experiments in lab classes play an important role in removing misconceptions.

In summary, the POE is a method that reveals misconceptions, facilitates meaningful learning by allowing students to mentally restructure various science concepts, generates more positive attitudes towards science, increases motivation and is easy to implement. Taking all these characteristics into consideration, it is thought that the principles of the POE method based on constructivist learning theory will be beneficial to teachers during the teaching process.

Several suggestions can be made to facilitate the use of the POE strategy:

Similar POE activities can be prepared to teach various subjects such as chemistry and other science disciplines based on the constructive learning theory.

Experimental studies that examine the effectiveness of the POE teaching method can be undertaken.

Studies can be designed that assess whether or not the POE teaching method is effective in other scientific and social disciplines.

Effects of the POE teaching method on the comprehension of teacher candidates in various disciplines regarding the constructivist learning theory and on their implementation skills of the theory can be examined.

The effects of introducing the POE teaching method to teachers can be investigated with regards to dissemination of principles generated through the constructivist learning theory in the teaching process.

\section{Acknowledgement}

Some results of this study was presented at the iSER 2014 World Conference, Cappadocia, Turkey.

\section{REFERENCES}

Ayas, A, (2006). Fen bilgisi öğretiminde laboratuar kullanımı. Anadolu Üniversitesi Açıöğretim Fakültesi Yayınları, Eskişehir.

Ayas, A., Çepni, S. \& Akdeniz, A. R. (1994). Fen bilimleri eğitiminde laboratuvarın yeri ve önemi; tarihsel bir bakış. Çăgdaş Ĕ̈itim Dergisi, 204, 21-25.

Bahar, M. (2003). Misconceptions in biology education and conceptual change strategies. Kuram ve Uygulamada Eğitim Bilimleri, 3(1), 55-64.

Bilen, K. (2009). Tahmin et-gözle-açıkla stratejisine dayalı laboratuvar uygulamalarının öğretmen adaylarının kavramsal başarılarına, bilimsel süreç becerilerine, tutumlarına ve bilimin doğası hakkındaki görüşlerine etkisi. Yayınlanmamış Doktora tezi, Gazi Üniversitesi, Eğitim Bilimleri Enstitüsü, Ankara.

Bilen, K. \& Aydoğdu, M. (2010). Fen bilgisi öğretmen adaylarına bitkilerde fotosentez ve solunum kavramlarını öğretmede TGA (Tahmin Et-Gözle-Açıkla) stratejisinin kullanımı. Mustafa Kemal Üniversitesi Sosyal Bilimler Enstitüsü Dergisi, 7(14), 179-194. 
Bilen ,K., \& Köse, S. (2012a). Yapılandırıcı öğrenme teorisine dayanan etkili bir öğretim stratejisi tga (tahmingözlem - açıklama), "bitkilerde büyüme ve gelişme”, Pamukkale Üniversitesi Ĕ̆itim Fakültesi Dergisi,1,121-134.

Bilen, K., \& Köse, S. (2012b). Kavram öğretiminde etkili bir strateji: tahmin-gözlem-açıklama (tga) bitkilerde madde taşınması.Mehmet Akif Ersoy Üniversitesi Eğitim Fakültesi Dergisi, 12(24), 21-42.

Bretz, S.L. \& Linenberger, K.J. (2012). Development of the enzyme-substrate interactions concept inventory. Biochemistry and Molecular Biology Education, HO, 229-233.

Clayton, W. M. C. (1993). Predict-observe-explain science activities in the junior high classroom- a qualitative inquiry. MED Thesis of Saint Mary's University, Canada.

Costello, P.J.M. (2007). Action research. Continuum Books: London

Driver, R. \& Bell, B. (1986). Students' thinking and the learning of science: a constructivist view. The School Science Review, 67(240), 443-456.

Ekici, G. (1996). Biyoloji öğretmenlerinin öğretimde kullandıkları yöntemler ve karşılaştıkları sorunlar. Yüksek lisans tezi, Ankara Üniversitesi Sosyal Bilimler Enstitüsü, Ankara.

Ekiz, D. (2003). Eğitimde araştırma yöntem ve metodlarına giriş: nitel, nicel veeleştirel kuram metodolojileri. Ankara: Anı Yayıncılık.

Emre, İ. \& Yılayaz, Ö. (2006). Fen bilgisi öğretmen adayların enzimlerle ilgili kavram yanılgıları. Doğu Anadolu Bölgesi Araştırmaları (Daum) Dergisi, 4 (3), 65-69.

Francis, J.W. \& Sellers, J.A. (1994). Studying amino acid sequence using word processing programs. American Biology Teacher,56(8), 484-487.

İşman,A. (1999). Eğitim teknolojisinin kuramsal boyutu: yapısalcı yaklaşımın(constructivisim) eğitim öğretim ortamlarına etkisi. Öğretmen Eğitiminde Çağdaş Yaklaşımlar Sempozyumu. Dokuz Eylül Üniversitesi Buca Eğitim Fakültesi, İzmir.

Kearney M. ve Treagust, D. F. (2001). Constructivism as a referent in the design and development of a computer program using interactive digital video to enhance learning in physics. Australian Journal of Educational Technology, 17(1), 64-79.

Köse, S., Bilen, K. \& Uçak, E. (2010). Predict-observe-explain (POE) strategy as a diagnostic tool to determine pre-service primary teachers' misconception on food synthesis of plants and photosynthesis. Proceedings of the 6th International Conference on Education, JULY 8-10, Samos Island, Greece, 96-105.

Köse, S., Coştu, B. \& Keser, Ö. F. (2003). Fen konularındaki kavram yanılgılarının belirlenmesi: tga stratejisi ve örnek etkinlikler. Pamukkale Üniversitesi Eğitim Fakültesi Dergisi, 13(1), 43-53.

Köseoğlu, F., Tümay, H. \& Kavak, N. (2002). Yapılandırıcı öğrenme teorisine dayanan etkili bir öğretim stratejisi -tahmin et, gözle, açıkla- buz ile su kaynatılabilir mi? V. Fen Bilimleri ve Matematik Eğitimi Kongresi, Orta Doğu Teknik Üniversitesi, 16-18 Eylül, Ankara.

Küçük, M. (2002). Hizmet-içi aksiyon araştırması kurs programının fen bilgisi ögretmenlerine uygulanması: bir örnek olay çalışması. Karadeniz Teknik Üniversitesi, Fen Bilimleri Enstitüsü, Yayımlanmamış Yüksek Lisans Tezi, Trabzon.

Lau, K. C. (2013). Seeing and feeling how enzyme works using tangible model.The American Biology Teacher, 75 (7), 499-501.

Lazarowitz, R. \& Penso, S. (1992). High school students' difficulties in learning biology concepts. Journal of Biolocigal Education, 26(3), 215-223.

Liew, C.-W. ve Treagust, D. F. (1995). A predict-observe-explain teaching sequence for learning about students' understanding of heat and expansion of liquids. AustralianScience Teachers' Journal, 41(1), 68-71.

Liew, C., ve Treagust, D. F. (1998). The effectiveness of predict-observe-explain tasks in diagnosing students' understanding of science and in identifying their levels of achievement. Paper Presented at the Annual Meeting of the American Educational Research Association, April 13-17, 22, San Diego, CA.

Linenberger, K.J. \& Brettz. S. L. (2015).Biochemistry students' ideas about how an enzyme interacts with a substrate.Biochemistry and Molecular Biology Education, 43(4), 213-22.

Mthembu, Z. P. (2001). Using predict, observe and explain technique to enhance students' understanding of chemical reactions. Unpublished paper (ongoing research). University of Natal King George V Natal.

Ministry of National Education of Turkey (2013). Elementary school science curriculum (grades 3-8). Ankara, Turkey.

National Research Council (1996). National science education standards [NSES]. Washington, DC: National Academic Press.

Russell, D., Lucas, K., \& Mcrobbie, C. (1999). Microprocessor based laboratory activities as catalysts for student construction of understanding in physics. Paper Presented at the Annual Meeting of the Australian Association forResearch in Education, Melbourne, Australia.

Sagor, R. (2000). Guiding school improvement with action research. Virginia: ASCD.

Selvi, M. \& Yakışan, M. (2004). Üniversite birinci sınıf öğrencilerinin enzimler konusu ile ilgili kavram yanılgıları. Gazi Üniversitesi Gazi Ë̆itim Fakültesi Dergisi, 24(2), 173-182. 
Sinan, O., Köse, S., Aydın, H., \& Gezer, K. (2007). Prospective science teachers conceptual understanding about proteins and protein synthesis. Journal of Applied Sciences, 7(21), 3154-3166.

Sinan, O., Yıldırım, O., Kocakülah, M. S. \& Aydın, H. (2006). Fen bilgisi öğretmen adaylarının proteinler, enzimler ve protein sentezi ile ilgili kavram yanılgıları. Gazi Üniversitesi Gazi Eğitim Fakültesi Dergisi, 26(1), 1-16.

Tao, P. K., \& Gunstone, R. F. (1999). The process of conceptual change in force and motion during computersupported physics instruction. Journal of Research in Science Teaching,36, 859-882.

Tekin, S. (2008). Kimya laboratuvarının etkililiğinin aksiyon araştırması yaklaşımıyla geliştirilmesi. Kastamonu Ë̆itim Dergisi, 16(2), 567-576.

Yeşilyurt, S. (2005). Biyoloji eğitimi öğrencilerinin biyoloji laboratuvar uygulamalarında karşılaştıkları güçlüklerin belirlenmesi üzerine bir araştırma. Çukurova Üniversitesi Ĕgitim Fakültesi Dergisi, 30(2), 8896.

Yip, D. Y. (1998). Teachers' misconceptions of the circulatory system. Journal of Biological Education, 32(3), 207-216. 